\title{
Costs of marriage-Marriage transactions in the developing world
}

\author{
Sajeda Amin \\ Population Council \\ Ashish Bajracharya \\ Population Council
}

Follow this and additional works at: https://knowledgecommons.popcouncil.org/departments_sbsr-pgy

Part of the Demography, Population, and Ecology Commons, Family, Life Course, and Society Commons, Gender and Sexuality Commons, International Public Health Commons, and the Medicine and Health Commons How does access to this work benefit you? Let us know!

\section{Recommended Citation}

Amin, Sajeda and Ashish Bajracharya. 2011. "Costs of marriage-Marriage transactions in the developing world," Promoting Healthy, Safe, and Productive Transitions to Adulthood Brief no. 35. New York: Population Council. 


\section{Costs of marriage-Marriage transactions in the developing world}

\section{Prepared by Sajeda Amin and Ashish Bajracharya}

0 ver the past two decades the Population Council has amassed a wealth of information on the causes and correlates of child marriage and documented its adverse effects on the wellbeing of women and girls. In many parts of the developing world, understanding child marriage is central to designing programs that promote healthy transitions to adulthood. Council research also underscores the importance of rituals and practices of marriage exchange around the globe and documents the considerable variation in these practices. This brief synthesizes some broad themes that have emerged from research on the costs of marriage. Even as customs such as dowry capture popular imagination and media attention, there is surprisingly little academic research or empirical evidence to inform judgment for effective programs and policy.

\section{Marriage Transactions}

Marriage transactions are payments or transfer of property that occur between families of the bride and groom during the time of a marriage. The form, direction, and scale of payments vary widely. In some settings, such as in Hindu or Sikh communities in Nepal or North India, negotiations about such payments are accepted practice; among Muslims in South Asia, on the other hand, the emergence of dowry demands has raised ire and alarm. The anthropological classic Bridewealth and Dowry (Goody and Tambiah 1973) provides simple but authoritative definitions of these transactions as follows:

Dowry: Transfers that flow from the bride's family to the groom's family.

Bridewealth/brideprice: Transfers that flow from the groom's family to the bride's family.

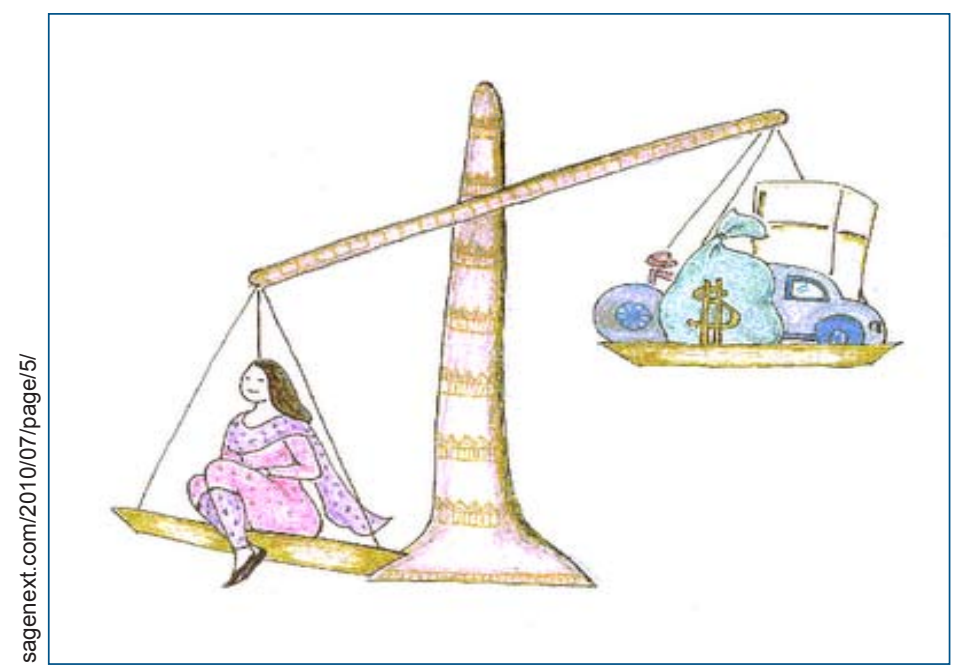

Beyond these are a host of other exchanges that take place during marriages. These may include the provision of services and the exchange of gifts or of sisters/daughters between families. While not overt economic transactions, these exchanges often have an underlying economic exchange function. Social scientists who study marriage exchange typically focus on trying to understand why transactions exist (e.g., Caldwell, Reddy, and Caldwell 1983; Becker 1991; Bhat and Halli 1999). However, the full range of consequences of marriage transactions is not well understood. Population Council work with adolescent girls suggests that along with the timing of marriage or practices such as child marriage, costs of marriage may have important implications for postmarital wellbeing and intimate-partner violence. In particular, the evaluation of women's and men's worth in the marriage market in terms of dowry or brideprice may have important consequences for 
their self-esteem and sense of self-worth, with significant implications for their wellbeing as adults and for gender equity. Yet, the evidence base on the consequences of the economic costs of marriage remains extremely weak.

\section{Static traditions versus changing practices}

There is good reason to believe that it is discontinuities in practices, and changes in expectations that are at issue rather than established and long-standing traditions. It is now well established that the costs of marriage have escalated in a wide range of settings. In a series of rigorous data assessments, the advent of dowry or its escalation over the past several decades has been linked to marriage squeeze (the excess of marriageable girls relative to boys). This is particularly well documented in South Asia. In Bangladesh and India the timing of rising dowry demands coincides with high rates of population growth, which, combined with a cultural preference for large age differences in marriage favoring grooms, creates an imbalance in the marriage market.

In many settings, costs of weddings have grown prohibitively expensive, with expenses totaling several times the total annual household income. This cost escalation may be attributed to rising aspirations and rising standards of living. When such expectations are not met, these practices have been linked to various negative influences on women's postmarital wellbeing, most frequently to the perpetration of severe forms of domestic violence.

Marriage transactions are often not completely rigid, but malleable and related to other desired marriage market attributes. Where the young age of a bride is a desirable attribute, poor families may choose to marry their daughters early to save on marriage costs. Similarly, unaffordable brideprice expectations may encourage young people to pursue relationships and childbearing outside marriage. Marriage-based transactions, whether in the form of dowry or brideprice, exacerbate the marginalization and exploitation of girls, particularly since both practices commoditize or monetize the value of girls. While brideprice appears to resemble more directly a transaction of purchasing a girl's reproductive and productive rights, dowry perpetuates the cycle of exploitation as well.

\section{Population Council's work on marriage transactions}

Population Council programs to prevent child marriage (Amin, Chong, and Haberland 2011) usually incorporate asset-building strategies for young women through education and livelihoods opportunities for girls. Research on the economic dimensions of marriage has informed these programming approaches for the wellbeing of girls. Council work on child marriage has evolved to incorporate multi-sectoral approaches that address the economic considerations of marriage. Given that marriage traditions and cultures, including the characteristics of marriage transactions, vary even within country contexts, programmatic approaches strive to be tailored to specific contexts. Some examples are presented below.

\section{Poverty and marriage timing in Nepal}

A study using national panel data from Nepal established a clear empirical link between being poor during childhood and getting married in early adolescence, rather than being enrolled in school (Bajracharya and Amin 2010). Dowry demands have risen in recent years. It is likely that this empirical linkage between marriage timing and poverty is mediated by marriage transactions. Instances of high demands for dowry and associated disagreements and violence are noted routinely in the popular press. However, dowry practices are afforded some legitimacy as long-standing traditions, and public critics have occasionally faced dire backlash, such as the murder of a radio journalist in southern Terai, who is believed to have been killed because of her public pronouncements against dowry. The southern Terai plains of Nepal have some of the most excessive dowry demands.

\section{Premarital pregnancy, education, and brideprice in South Africa}

The payment of a brideprice (lobola), common in South African marriages, symbolizes the transfer of the right of the girl's sexual and economic services to the husband (Meekers 1992). A study in South Africa that examined premarital pregnancy and parenthood during adolescence (Kaufman, de Wet, and Stadler 2000) cites lobola as an important factor in determining marriageability of girls who have had children. On the basis of qualitative research, Council researchers concluded that the expectation of brideprice may motivate parents to invest in a girl's education and could explain the unusual South African pattern where most girls returned to school even after childbirth. Births outside of marriage and premarital births during adolescence were also related to lower brideprice for girls for their future marriages, giving rise to circumstances where premarital births were often kept a secret.

\section{Transformation of marriage and reproductive behavior in Ghana} A study by Council researchers on the changing nature of reproductive behavior in Ghana examined the role of brideprice in explaining the declining importance of marriage and rising premarital sex and childbearing (Mensch et al. 1999). The qualitative results suggested that traditional courtship traditions that involved a large brideprice were viewed as a burden for young men. Along with the declining practice of female circumcision, premarital sexual activity had become increasingly common and young people's sexual lives were no longer confined within traditional marriage. As young couples increasingly exercise control over life decisions such as marriage and childbearing, they favor bypassing tradi- 
tional marriage customs, effectively circumventing the financial burden in the process. Customary practices of large brideprice are a disincentive to formal marriages, and contribute to the erosion of traditional marriage and family formation in this region in Ghana.

\section{Unintended consequences of delaying marriage in Bangladesh}

According to DHS data, over 65 percent of women between the ages of 20 and 24 in Bangladesh are married before 18. In 2001, the Population Council partnered with several UN and nongovernmental agencies in Bangladesh to design and evaluate a large-scale program for adolescent girls called Kishori Abhijan (Amin and Suran 2005). Kishori Abhijan focused on creating safe spaces for girls to socialize and learn, and provided training to enhance livelihood skills. The goal was to challenge rigid social norms such as early marriage by empowering girls economically and socially. Monitoring of program components showed that the safe spaces and social support components of the program were consistently implemented and well accepted. Livelihoods training, by contrast, proved to be expensive and difficult to conduct at scale. Consequently, only a fraction of the girls were able to participate in livelihood training. An evaluation conducted two years into the program found that although marriage was delayed for program participants, dowry payments increased in tandem with age at marriage. In Bangladesh there is a strong association between age at marriage and amounts of dowry paid (see Figure 1). The program has subsequently attempted to address dowry by working with families, but has found it to be an intractable problem. While safe spaces and social support programs are successful in delaying marriage, demands for dowry come from the boys and men whom the girls marry. In a society where marriage is highly valued and deter-

Figure 1 Mean dowry and age at marriage in Bangladesh

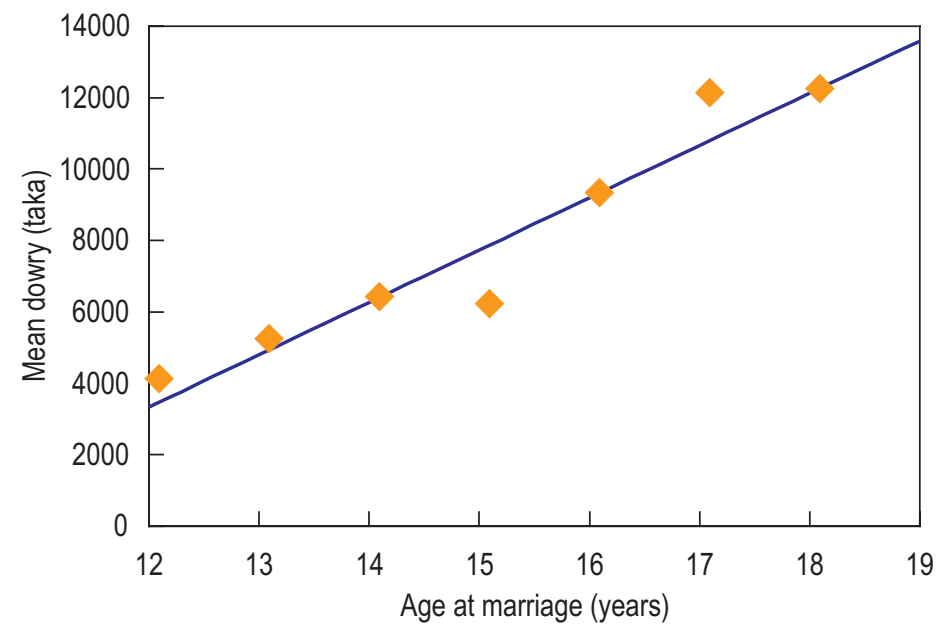

From Kishori Abhijan data on girls marrying between 2001 and 2003. mines the social and economic status of girls, the rejection of marriage prospects because of dowry costs is not an option for most families.

\section{Data on marriage transactions from survey research}

Notwithstanding these studies, our efforts at understanding marriage transactions and the consequences for the wellbeing of girls and women have been limited by a lack of data. Nationally representative household surveys such as the Living Standards Measurement Surveys of the World Bank (LSMS) or the Demographic and Health Surveys (DHS) often collect data only on age at marriage and spousal characteristics. Among surveys that address marriage and family formation more specifically, a few surveys collect data on a wider variety of marriage-related variables. The 2006 World Bank Gender Norms Survey in Bangladesh is exemplary in its detailed collection of data on marriage characteristics and on marriage transactions (World Bank 2008). This dataset collects information on several marriage themes that researchers agree are instrumental in conducting rigorous empirical research on transactions and marriage dynamics. These themes are as follows:

\section{Arrangement of marriage}

2. Spousal choice

3. Asset and wealth differentials between families

4. Presence of village endogamy

\section{Patterns in postmarital residence}

The World Bank survey is also particularly detailed in its questions on marriage transactions in Bangladesh. Themes listed below on marriage transactions are likely to be instrumental in enhancing the understanding of the role marriage transactions play in marriage timing and of a host of postmarital wellbeing outcomes and status indicators:

1. Whether money and materials were transferred.

2. The amount of the exchange, monetary or otherwise.

3. Whether the transfers were voluntary or demanded by one family from another.

4. How families meet demands (including taking on debt) and whether demands exceed what a typical family can pay.

5. Whether negotiations about what and how much is to be exchanged occurred and whether a paid middleman was involved.

6. How families acquire financial resources to pay for a dowry or brideprice. 
Researchers at the Population Council have begun taking stock of the kinds of quantitative survey data that are available on marriage transactions. Recent reviews suggest that large-scale data that address these themes and questions do not exist at a national level. Much of the research conducted on this topic thus invariably comes from small, localized, and unrepresentative samples, severely reducing the generalizability of the findings. Initiatives that drive the collection of such data would positively affect studies on marriage transactions at the national level, with significant potential for delivering policy-relevant research.

\section{Conclusions}

Although the lack of an appropriate evidence base is clearly a hindrance to exploring marriage costs fully, this review highlights several important aspects of marriage transactions. Our research has shown that in many parts of the world, the costs of marriage are drivers of social change. Even while practices are widely varied, the consequences for women are overwhelmingly negative. As programs to promote healthy transitions to adulthood take root and proliferate in diverse contexts, particular manifestations of marriage costs and their correlates need to be taken into account, both in terms of understanding change that is already underway, and for designing programs to bring about change.

Some of the examples, such as the experience in Bangladesh, show how a nuanced understanding may avoid unintended consequences of programs that target a specific practice such as child marriage. The case of Nepal emphasizes the importance of targeting the poor, who may be more adversely affected by these practices. On the other hand, the specific norms of exchange in Egypt and Pakistan may have helped to prop up traditions of late marriage for women. Processes of development and modernization, such as urbanization and migration, may well erode the basis of these norms, leading to a downward pressure on age at marriage.

Recent efforts, such as the social norms approach to programming promoted by UNICEF, suggest a starting point. Indeed, an important contribution is in the naming of the approach and its insistence that norms exists and need to be addressed. Without appropriate evidence on what the norms are, how they function, and with what consequences, however, it is difficult to see how the approach itself would proceed.

\section{References and related publications}

Amin, S., E. Chong, and N. Haberland. 2011. "Programs to address child marriage: Framing the problem," Promoting Healthy, Safe, and Productive Transitions to Adulthood Brief No. 14. New York: Population Council.

Amin, S. and M. Das. 2009. "Marriage continuity and change in Bangladesh," Paper presented at Seminar on Marriage, Indian Institute of Technology, New Delhi, 25-27 September (forthcoming as book chapter).

Amin, S. and L. Suran. 2005. "Program efforts to delay marriage through improved opportunities: Some evidence from rural Bangladesh," Paper presented at the International Union for the Scientific Study of Population (IUSSP). Tours, France, 18-23 July.

Bajracharya, A. and Amin, S. 2010. "Poverty, marriage timing, and transitions to adulthood in Nepal: A longitudinal analysis using the Nepal Living Standards Survey," Poverty, Gender, and Youth Working Paper. No. 19. New York: Population Council.

Becker, G. 1991. A Treatise on the Family. Cambridge, MA: Harvard University Press.

Bhat, P.N.M. and S.S. Halli. 1999. "Demography of brideprice and dowry: Causes and consequences of the Indian marriage squeeze," Population Studies 53(2): 129- 148

Caldwell, J., P.H. Reddy, and P. Caldwell. 1983. "The causes of marriage change in South India," Population Studies 37(3): 343-361.

Goody, J. and Tambiah, S.J. 1973. Bridewealth and Dowry. Cambridge University Press.

Kaufman, C.E., T. de Wet, and J. Stadler. 2000. "Adolescent pregnancy and parenthood in South Africa," Policy Research Division Working Paper No. 136. New York: Population Council.

Meekers, D. 1992. "The process of marriage in African societies: A multiple indicator approach," Population and Development Review 18(1): 61-78.

Mensch, B., D. Bagah, W. Clark, and F. Binka. 1999. "The changing nature of adolescence in the Kassena-Nankana district of northern Ghana," Studies in Family Planning 30(2): 95-111.

Suran, L., S. Amin, L. Huq, and K. Chowdury. 2004. "Does dowry improve life for brides? A test of the bequest theory of dowry in rural Bangladesh," Policy Research Division Working Paper No. 195. New York: Population Council.

World Bank. 2008. "From whispers to voices: Gender and social transformation in Bangladesh," Bangladesh Development Series. Washington, DC: World Bank.

\section{Population Council}

The Population Council changes the way the world thinks about critical health and development issues. We seek to understand the causes and consequences of gender inequality and the disparities in opportunity that arise during adolescence. We provide the evidence for better on-theground programs and policies that ensure successful and productive transitions to adulthood in developing countries. www.popcouncil.org

(c) 2011 The Population Council, Inc. 